\title{
PENGGUNAAN MULTIMEDIA DALAM PEMBELAJARAN PAI UNTUK MENINGKATKAN HASIL BELAJAR SISWA KELAS IX C SMP NEGERI 2 CIAMIS
}

\author{
Yuyun Yunani \\ SMPN 2 Ciamis, Jl. Jend. Sudirman No.241, Sindangrasa, Ciamis, Indonesia \\ Email: y_yunani@rocketmail.com
}

\begin{abstract}
This study aims to improve the ability of teachers to plan, implement and describe student learning outcomes using multimedia in Islamic Religious Education learning of class IX C SMP Negeri 2 Ciamis. Classroom Action Research (CAR) or Classroom Action Research (PTK) is employed. The research subjects are 30 students of class IX C SMP Negeri 2 Ciamis in the academic year of 2017/2018. The data are collected through interviews, observation, and tests. The data obtained are used as material for reflection, and subsequently, it is utilized as a reference in planning learning of next cycle. While the data analysis technique used is descriptive analysis which is elaborated by frequency and percentage of student learning outcomes. The results of this study indicate that 1) The planning for the use of multimedia in Islamic Religious Education learning with the material of qurban and aqiqah in the first cycle is classified as good, covering $70 \%$. Then, there is an increase in cycles II and III, each of which obtains a good value of 100\%; 2) The use of multimedia in learning Islamic Religious Education on qurban and aqiqah material increases starting from cycle I covering $80 \%$, followed by cycle $/$ 97\% and cycle III 100\%; 3) Student learning outcomes have increased significantly. The average cycle I is 83 with classical completeness $83 \%$, increased in cycle II to 88 with classical completeness of $86.7 \%$ and increases again in cycle III (90.2) with $100 \%$ classical completeness..
\end{abstract}

Keywords: Multimedia, Learning Outcomes

\section{ABSTRAK}

Penelitian ini bertujuan untuk meningkatkan kemampuan guru dalam merencanakan, melaksanaan dan mendeskripsikan hasil belajar siswa menggunakan multimedia dalam pembelajaran PAI kelas IX C SMP Negeri 2 Ciamis. Jenis penelitian yang digunakan adalah Classroom Action Research (CAR) atau penelitian tindakan kelas (PTK). Subyek penelitian berjumlah 30 siswa kelas IX C SMP Negeri 2 Ciamis tahun pelajaran 2017/2018. Metode pengumpulan data menggunakan wawancara, observasi, dan tes. Data yang terkumpul digunakan sebagai bahan refleksi. Kemudian hasil refleksi tersebut dijadikan acuan untuk merencanakan pembelajaran pada siklus berikutnya. Sedangkan teknik analisis data yang digunakan adalah analisis deskriptif yaitu berupa pemaparan frekuensi dan persentase hasil belajar siswa. Hasil penelitian ini menunjukkan bahwa 1) Perencanaan penggunaan multimedia dalam pembelajaran PAI materi qurban dan aqiqah pada siklus I tergolong baik mencapai $70 \%$. Kemudian terjadi peningkatan pada siklus II dan III, dengan masing-masing diperoleh nilai baik menjadi 100\%; 2) Penggunaan multimedia dalam pembelajaran PAl materi qurban dan aqiqah mengalami peningkatan mulai dari siklus I memperoleh nilai baik mencapai $80 \%$, siklus II 97\% dan siklus III 100\%; 3) Hasil belajar siswa mengalami peningkatan yang signifikan. Rata-rata siklus I sebesar 83 dengan ketuntasan klasikal $83 \%$, meningkat pada siklus II menjadi 88 dengan ketuntasan klasikal $86,7 \%$ dan meningkat lagi pada siklus III menjadi 90,2 dengan ketuntasan klasikal 100\%.

Kata kunci: Multimedia, Hasil Belajar

Cara sitasi: Yunani, Y. (2020). Penggunaan Multimedia dalam Pembelajaran PAl untuk Meningkatkan Hasil Belajar Siswa Kelas IX C SMP Negeri 2 Ciamis. J-KIP (Jurnal Keguruan dan IImu Pendidikan), 1 (2), 55-62. 


\section{PENDAHULUAN}

Pendidikan Agama Islam ialah usaha sadar untuk menyiapkan peserta didik dalam meyakini, memahami, menghayati, dan mengamalkan agama Islam melalui kegiatan bimbingan, pengajaran dan/atau pelatihan dengan memperhatikan tuntutan untuk menghormati agama lain dalam hubungan kerukunan antar umat beragama dalam masyarakat untuk mewujudkan persatuan nasional. Menurut Buchori (1994), Pendidikan Agama Islam adalah segenap kegiatan yang dilakukan seseorang atau lembaga untuk menanamkan nilai-nilai Islam dalam diri sejumlah siswa. Nilai Islam di sini adalah akhlak mulia yang mencakup etika, budi pekerti, dan moral sebagai perwujudan dari pendidikan agama.

Proses belajar mengajar adalah sebuah kegiatan yang integral (utuh terpadu) antara siswa sebagai pelajar yang sedang belajar dengan guru sebagai pengajar yang sedang mengajar. Dalam kegiatan ini terjadi interaksi resiprokal, yakni hubungan antara guru dengan para siswa dalam situasi instruksional, yaitu suasana yang bersifat pengajaran (Syah, 2006). Dengan demikian dapat ditarik kesimpulan bahwa dalam proses belajar mengajar pasti melibatkan dua komponen penting, yakni guru dan siswa. Komponen lain yang tidak kalah penting yaitu tujuan, bahan, metode, media yang tersedia, alat evaluasi, dan suasana evaluasi (Fathurrohman, 2001).

Satu di antara komponen penting dalam proses pembelajaran adalah guru. Betapa signifikan (berarti penting) posisi guru dalam dunia pendidikan (Syah, 2006). Hal ini diperkuat dengan tugas guru dalam pendidikan Islam adalah mendidik, yang berarti mengupayakan perkembangan seluruh potensi peserta didik, baik potensi psikomotor, kognitif, maupun potensi afektif. Tugas utama yang lainnya adalah mengajar, yakni memberikan dorongan, memuji, menghukum, memberi contoh, membiasakan, dan lain-lain. Ahmad (2004) berpendapat bahwa tugas guru sebagian besar adalah mendidik dengan cara mengajar.

Pembelajaran tidak selamanya bersentuhan dengan hal-hal yang konkret, baik dalam konsep maupun faktanya. Tetapi realitanya bersentuhan dengan hal-hal yang bersifat kompleks, dan maya. Karena itu media memiliki andil untuk menjelaskan hal-hal yang abstrak dan menunjukkan hal-hal yang tersembunyi. Ketidakjelasan atau kerumitan bahan ajar dapat dibantu dengan menghadirkan media sebagai perantara. Bahkan dalam hal-hal tertentu media dapat mewakili kekurangan guru dalam mengkomunikasikan materi pelajaran. Meski media cukup penting dalam pembelajaran, tetap tidak bisa menggeser peran guru, karena media hanya berupa alat bantu memfasilitasi pembelajaran. Banyak ragam dan jenis media yaitu: audio, visual, dan audio visual. Penggunaannya dalam proses pembelajaran ada yang satu macam atau bermacam-macam. Seiring dengan perkembangan ilmu pengetahuan dan teknologi komunikasi/informasi yang semakin cepat dan pesat, maka seorang guru harus mampu menggabungkan beberapa jenis media untuk disatukan penggunaannya dalam pembelajaran, yang dikenal dengan multimedia.

Pengalaman penulis ketika mengajar di SMP negeri 2 Ciamis, terutama ketika menyajikan beberapa materi pembelajaran PAI di Kelas IX C, penulis merasa sudah cukup maksimal untuk mengajar, tetapi faktanya respon siswa terhadap penyajian materi pelajaran kurang kondusif. Artinya ada sejumlah siswa yang masih ribut, tidak memperhatikan materi, ngantuk, tidak mengerti materi yang disajikan, dan tidak mengerjakan tugas atau perintah guru. Aktivitas belajar siswa yang demikian berdampak pada hasil belajar mereka pada materi pelajaran PAI yang rata-ratanya kurang dari pencapaian Kriteria Ketuntasan Minimal (KKM). Data terakhir pada hasil belajar siswa melalui post test menunjukkan bahwa pencapaian rata-ratanya sebesar 70 dengan ketuntasan klasikal hanya $40 \%$. Angka 70 meskipun tergolong cukup menurut skala kriteria hasil belajar yang umum (skala 0-100), namun belum mencapai angka Kriteria Ketuntasan Minimal (KKM) yang ditetapkan oleh guru agama di SMP Negeri 2 Ciamis, yakni 76. Realita ini menunjukkan adanya permasalahan atau kesenjangan antara usaha maksimal guru agama dalam mengajar dengan rendahnya aktivitas dan hasil belajar siswa. Hal ini bisa terjadi karena penyajian penulis terlalu cepat, gaya mengajar yang monoton, metode yang digunakan kurang menarik, tidak menggunakan media pembelajaran yang representatif, 
penguasaan pengelolaan kelas yang kurang, dan sebagainya. Oleh karena itu penulis berkeyakinan bahwa media pembelajaran multimedia menjadi solusi dalam pembelajaran PAI.

Berdasarkan realita dan analisa terhadap permasalahan tersebut maka tujuan penelitian ini adalah :(1) Mendeskripsikan kemampuan guru dalam merencanaan pembelajaran PAI dengan menggunakan multimedia di Kelas IX C SMP Negeri 2 Ciamis; (2) Mendeskripsikan kemampuan guru dalam melaksanaan pembelajaran PAI dengan menggunakan multimedia di kelas IX C SMP Negeri 2 Ciamis; (3) Mendeskripsikan hasil belajar siswa dengan menggunakan multimedia dalam pembelajaran PAI Kelas IX C SMP Negeri 2 Ciamis.

\section{METODE PENELITIAN}

Penelitian ini menggunakan pendekatan penelitian tindakan kelas, lokasi penelitian dilaksanakan di SMP Negeri 2 Ciamis dengan subyek penelitianya adalah kelas IX C yang berjumlah 30 siswa yang terlibat dalam pembelajaran Pendidikan Agama Islam dan Budi Pekerti dengan materi pokok Qurban dan Aqikah. Desain penelitian meliputi dua siklus dan tiap siklus terdiri dari dua pertemuan. Dalam penelitian tindakan kelas ini peneliti mengadopsi model yang dikembangkan Kurt Lewin, Kemmis, dan Mc Taggart. Adapun komponen-komponen pokok yang dijadikan sebagai langkah dalam penelitian ini adalah: perencanaan (planning), tindakan (acting), pengamatan (observing), dan refleksi (reflecting). Prosedur penelitian ini dapat divisualisasikan sebagai berikut:

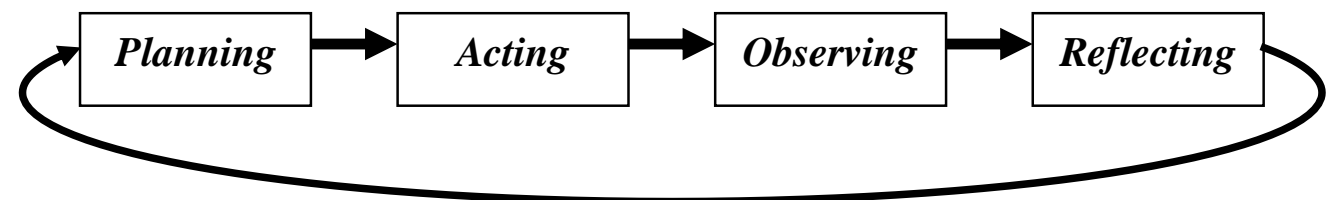

Untuk mengetahui optimalnya perencanaan dan penggunaan multimedia dalam pembelajaran PAl, maka dilakukan observasi terhadap kegiatan perencanaan dan pelaksanaan pembelajaran di kelas dengan menggunakan instrument lembar observasi dan tes isian untuk diisi oleh siswa di akhir siklus. Sebagai penguatan respon siswa terhadap penggunaan multimedia yang disajikan oleh guru agama, peneliti menyebarkan angket kepada seluruh siswa di kelas tersebut dan melakukan wawancara dengan guru. Data hasil penelitian ini meliputi data kuantitatif dan data kualitatif. Data kuantitatif yang diperoleh dari tes hasil belajar dan lembar observasi kinerja guru ketika proses pembelajaran di kelas. Sedangkan data kualitatif diperoleh dari isian angket sebagai tanggapan siswa terhadap penggunaan multimedia dan jawaban hasil wawancara dengan guru pengamat.

\section{HASIL DAN PEMBAHASAN}

Penelitian ini dilakukan dengan tiga siklus. Hasil penelitian tiap siklus disajikan sebagai berikut:

\section{a. Siklus I}

Tabel 1. Hasil Pretest dan Postest

\begin{tabular}{lcc}
\hline \multicolumn{1}{c}{ Keterangan } & Pretest & Postest \\
\hline Rata-rata & 53 & 83 \\
Nlai tertinggi & 90 & 100 \\
Nilai terendah & 20 & 50 \\
Ketuntasan klasikal (\%) & 30 & 83 \\
\hline
\end{tabular}

Berdasarkan Tabel 1 diperoleh data bahwa rata-rata, nilai tertinggi, nilai terendah dan ketuntasan klasikal pretes lebih kecil dari postes. 
Tabel 2. Hasil Observasi Aktivitas Peneliti

\begin{tabular}{|c|c|c|c|c|}
\hline \multirow{2}{*}{ No } & \multirow{2}{*}{ Aspek Yang Diamati } & \multicolumn{3}{|c|}{ Kriteria } \\
\hline & & B & C & $\mathrm{K}$ \\
\hline 1 & $\begin{array}{l}\text { Ketersediaan multimedia nampaknya } \\
\text { betul-betul direncanakan }\end{array}$ & $\checkmark$ & & \\
\hline 2 & $\begin{array}{l}\text { Urutan langkah-langkah dalam RPP } \\
\text { sesuai dengan Kurikulum } 2013 \\
\text { Tujuan dan indikator pembelajaran dalam }\end{array}$ & $\checkmark$ & & \\
\hline 3 & $\begin{array}{l}\text { RPP sesuai dengan Kompetensi Dasar } \\
\text { (KD) dan IPK }\end{array}$ & $\checkmark$ & & \\
\hline 4 & $\begin{array}{l}\text { Materi pembelajaran dalam RPP sesuai } \\
\text { dengan tujuan dan indikator } \\
\text { pembelajaran }\end{array}$ & $\checkmark$ & & \\
\hline 5 & $\begin{array}{l}\text { Dalam kegiatan pembelajaran, nampak } \\
\text { sekali skenario penggunaan multimedia }\end{array}$ & $\checkmark$ & & \\
\hline 6 & Metode yang direncanakan bervariasi & $\checkmark$ & & \\
\hline 7 & $\begin{array}{l}\text { Rencana metode sesuai dengan } \\
\text { rumusan tujuan dan indikator } \\
\text { pembelajaran } \\
\text { Model pendekatan yang dirancang dalam }\end{array}$ & $\checkmark$ & & \\
\hline 8 & $\begin{array}{l}\text { RPP merupakan penggabungan antara } \\
\text { teacher centered dengan student } \\
\text { centered }\end{array}$ & & $\checkmark$ & \\
\hline 9 & $\begin{array}{l}\text { Soal-soal penilaian dalam RPP sesual } \\
\text { dengan tujuan, indikator, dan materi } \\
\text { pembelajaran }\end{array}$ & & $\checkmark$ & \\
\hline 10 & $\begin{array}{l}\text { Bentuk dan jenis tes dapat mengukur } \\
\text { kemampuan siswa dalam menguasai } \\
\text { materi pelajaran }\end{array}$ & & $\checkmark$ & \\
\hline & Jumlah & 7 & 3 & - \\
\hline
\end{tabular}

Berdasarkan Tabel 2 diperoleh informasi bahwa hasil observasi aktivitas peneliti menunjukkan nilai $B$ ada 7 poin dan nilai $c$ ada 3 poin.

b. Siklus II

Tabel 3. Hasil Pretest dan Postest

\begin{tabular}{lcc}
\hline \multicolumn{1}{c}{ Keterangan } & Pretest & Postest \\
\hline Rata-rata & 63 & 88 \\
Nlai tertinggi & 80 & 100 \\
Nilai terendah & 50 & 70 \\
Ketuntasan klasikal (\%) & 40 & 86.70 \\
\hline
\end{tabular}

Berdasarkan Tabel 3 diperoleh data bahwa rata-rata, nilai tertinggi, nilai terendah dan ketuntasan klasikal pretes lebih kecil dari postes.

Tabel 4. Hasil Observasi Aktivitas Peneliti

\begin{tabular}{clccc}
\hline No & \multicolumn{1}{c}{ Aspek Yang Diamati } & Kriteria & \\
\hline 1 & $\begin{array}{l}\text { Ketersediaan multimedia nampaknya betul- } \\
\text { betul direncanakan }\end{array}$ & $\checkmark$ & & K \\
\hline & $\begin{array}{l}\text { Urutan langkah-langkah dalam RPP sesuai } \\
\text { dengan Kurikulum } 2013\end{array}$ & &
\end{tabular}




\begin{tabular}{|c|c|c|c|c|}
\hline \multirow{2}{*}{ No } & \multirow{2}{*}{ Aspek Yang Diamati } & \multicolumn{3}{|c|}{ Kriteria } \\
\hline & & B & C & $\mathrm{K}$ \\
\hline 3 & $\begin{array}{l}\text { Tujuan dan indikator pembelajaran dalam } \\
\text { RPP sesuai dengan Kompetensi Dasar (KD) } \\
\text { lPn IPK }\end{array}$ & $\checkmark$ & & \\
\hline 4 & $\begin{array}{l}\text { Materi pembelajaran dalam RPP sesuai } \\
\text { dengan tujuan dan indikator pembelajaran }\end{array}$ & $\checkmark$ & & \\
\hline 5 & $\begin{array}{l}\text { Dalam kegiatan pembelajaran, nampak sekali } \\
\text { skenario penggunaan multimedia }\end{array}$ & $\checkmark$ & & \\
\hline 6 & Metode yang direncanakan bervariasi & $\checkmark$ & & \\
\hline 7 & $\begin{array}{l}\text { Rencana metode sesuai dengan rumusan } \\
\text { tujuan dan indikator pembelajaran }\end{array}$ & $\checkmark$ & & \\
\hline 8 & $\begin{array}{l}\text { Model pendekatan yang dirancang dalam } \\
\text { RPP merupakan penggabungan antara } \\
\text { teacher centered dengan student centered } \\
\text { Soal-soal penilaian dalam RPP sesuai }\end{array}$ & $\checkmark$ & & \\
\hline 9 & $\begin{array}{l}\text { dengan tujuan, indikator, dan materi } \\
\text { pembelajaran } \\
\text { Bentuk dan jenis tes dapat mengukur }\end{array}$ & $\checkmark$ & & \\
\hline 10 & $\begin{array}{l}\text { kemampuan siswa dalam menguasai materi } \\
\text { pelajaran }\end{array}$ & $\checkmark$ & & \\
\hline & Jumlah & 10 & - & - \\
\hline
\end{tabular}

Berdasarkan Tabel 4 diperoleh informasi bahwa hasil observasi aktivitas peneliti menunjukkan nilai $B$ ada 10 poin dan nilai $c$ ada 3 poin.

\section{b. Siklus III}

Tabel 5. Hasil Pretest dan Postest

\begin{tabular}{lcc}
\hline \multicolumn{1}{c}{ Keterangan } & Pretest & Postest \\
\hline Rata-rata & 70,2 & 90,2 \\
Nlai tertinggi & 80 & 100 \\
Nilai terendah & 60 & 75 \\
Ketuntasan klasikal (\%) & 50 & 100 \\
\hline
\end{tabular}

Berdasarkan Tabel 5 diperoleh data bahwa rata-rata, nilai tertinggi, nilai terendah dan ketuntasan klasikal pretes lebih kecil dari postes.

Tabel 6. Hasil Observasi Aktivitas Peneliti

\begin{tabular}{clccc}
\hline No & \multicolumn{1}{c}{ Aspek Yang Diamati } & & Kriteria & \\
\hline 1 & $\begin{array}{l}\text { Ketersediaan multimedia nampaknya betul- } \\
\text { betul direncanakan }\end{array}$ & $\checkmark$ & & K \\
2 & $\begin{array}{l}\text { Urutan langkah-langkah dalam RPP sesuai } \\
\text { dengan Kurikulum 2013 }\end{array}$ & $\checkmark$ & \\
3 & $\begin{array}{l}\text { Tujuan dan indikator pembelajaran dalam } \\
\text { RPP sesuai dengan Kompetensi Dasar (KD) } \\
\text { dan IPK }\end{array}$ & $\checkmark$ & \\
4 & $\begin{array}{l}\text { Materi pembelajaran dalam RPP sesuai } \\
\text { dengan tujuan dan indikator pembelajaran }\end{array}$ & $\checkmark$ & \\
5 & $\begin{array}{l}\text { Dalam kegiatan pembelajaran, nampak sekali } \\
\text { skenario penggunaan multimedia } \\
\text { Metode yang direncanakan bervariasi }\end{array}$ & $\checkmark$ & \\
6 & $\checkmark$ & \\
\hline
\end{tabular}




\begin{tabular}{|c|c|c|c|c|}
\hline \multirow{2}{*}{ No } & \multirow{2}{*}{ Aspek Yang Diamati } & \multicolumn{3}{|c|}{ Kriteria } \\
\hline & & B & C & K \\
\hline 7 & $\begin{array}{l}\text { Rencana metode sesuai dengan rumusan } \\
\text { tujuan dan indikator pembelajaran }\end{array}$ & $\checkmark$ & & \\
\hline 8 & $\begin{array}{l}\text { Model pendekatan yang dirancang dalam } \\
\text { RPP merupakan penggabungan antara } \\
\text { teacher centered dengan student centered }\end{array}$ & $\checkmark$ & & \\
\hline & Soal-soal penilaian dalam RPP sesuai & & & \\
\hline 9 & $\begin{array}{l}\text { dengan tujuan, indikator, dan materi } \\
\text { pembelajaran }\end{array}$ & $\checkmark$ & & \\
\hline 10 & $\begin{array}{l}\text { Bentuk dan jenis tes dapat mengukur } \\
\text { kemampuan siswa dalam menguasai materi } \\
\text { pelajaran }\end{array}$ & $\checkmark$ & & \\
\hline & Jumlah & 10 & - & - \\
\hline
\end{tabular}

Berdasarkan Tabel 6 diperoleh informasi bahwa hasil observasi aktivitas peneliti menunjukkan nilai $B$ ada 10 poin dan nilai $c$ ada 3 poin.

Penelitian ini dilakukan dengan tiga siklus yang masing-masing siklusnya akan dibahas dengan rinci sebagai berikut:

\section{a. Temuan hasil penelitian siklus 1}

Berdasarkan pengolahan data siklus 1 yang terdiri dari perencanaan, tindakan, observasi, dan refleksi. Temuan-temuannya antara lain :

1) Penggunaan multimedia yang sudah dilakukan oleh guru agama SMP Negeri 2 Ciamis selama ini perlu dipertahankan, dikembangkan, serta ditingkatkan penggunaannya dalam pembelajaran, termasuk bagi guru mata pelajaran lainnya. Apalagi hampir seluruh siswa menyatakan sangat menarik jika pembelajaran dibantu dengan multimedia.

2) Kekuatan atau keunggulan lain dari penggunaan multimedia oleh guru PAI adalah dalam penerapannya tidak akan berdampak negatif, tidak menimbulkan ekses yang jelek, sebab sebagai seorang guru agama tentu memahami betul akan aturan-aturan dan norma yang ada.

3) Variasi penggunaan metode dalam mempresentasikan materi melalui multimedia sangat baik sehingga perlu terus dipertahankan dan digunakan dalam setiap proses pembelajaran.

4) Sumber daya siswa dengan karakteristik yang berbeda-beda serta ketersediaan dana bagi penyediaan sarana dan prasarana di SMP Negeri 2 Ciamis menjadi tantangan sekaligus peluang bagi guru agama untuk lebih mengembangkan potensi yang ada.

5) Dalam presentasi kegiatan awal pembelajaran materi Qurban, guru agama tidak mengkomunikasikan secara lengkap dan baik tujuan pembelajaran yang akan dicapai pada pertemuan tersebut.

6) Biasanya dalam penggunaan multimedia, diselipkan game-game menarik sebagai upaya jeda dan hiburan sejenak bagi siswa, supaya mereka lebih segar dan bersemangat untuk melanjutkan aktivitas belajarnya. Hal itu tidak ditemukan dalam penggunaan multimedia siklus I.

7) Dalam pelaporan hasil diskusi kelompok yang hanya memberi kesempatan kepada dua kelompok saja, akan menimbulkan kecemburuan dan kurang merasa dihargai oleh guru agama dari kelompok lain. Sebaiknya semua kelompok diberi kesempatan melaporkan hasil kerjanya.

8) Penyajian soal-soal seperti kuiz yang dipresentasikan dalam power point di satu sisi memang menarik, menantang siswa, siswa menjadi antusias untuk memperhatikan dan menjawabnya, akan tetapi di sisi lain karena terbatasnya waktu penayangan tiap soal, bagi siswa yang agak lambat merespon tiap soal tidak akan bisa mereviu/meminta pengulangan soal-soal terdahulu 
yang masih dirasakan sulit mencari jawabannya. Karena itu disamping ditayangkan dalam

b. Temuan Hasil Penelitian Siklus II

layar, soal-soal tersebut sebaiknya disertakan bersama dengan lembar jawaban.

Temuan-temuan pada siklus kedua antara lain:

1) Penggunaan multimedia yang dilakukan oleh guru agama SMP Negeri 2 Ciamis sangat baik dan perlu dikembangkan dan ditransferkan pada guru lain.

2) Game-game yang menarik ketika jeda, meski hanya beberapa menit menambah antusias dan segarnya kembali ingatan siswa sehingga mereka tidak jenus dan tidak akan ngantuk.

3) Kemampuan menyajikan materi lewat multimedia menjadi amat penting bagi guru agama yang terampil, akan tetapi bagi guru yang belum terampil justru tidak menjadi prioritas dalam memanfaatkan media alat bantu pembelajaran.

4) Siswa semakin antusias dengan hadirnya kembali pemanfaatan multimedia oleh guru agama dalam materi tatacara penyembelihan hewan qurban. Ini menjadi modal berharga bagi guru agama untuk lebih kreatif lagi dalam mendayagunakan multimedia yang ada.

5) Pengelompokkan siswa tidak merata, dengan jumlah siswa 30 orang, maka ada satu kelompok yang hanya dua orang, sementara yang lain berjumlah empat orang.

Berdasarkan refleksi tersebut maka diputuskan untuk mengadakan tahapan siklus ketiga karena ditinjau dari hasil tes siswa siklus II masih bisa ditingkatkan kembali.

c. Temuan Hasil Penelitian Siklus III

Temuan-temuan pada siklus ketiga antara lain:

1) Penggunaan multimedia yang dilakukan oleh guru agama SMP Negeri 2 Ciamis sangat baik dan ditransferkan pada guru mata pelajaran lain.

2) Kemampuan menyajikan materi lewat multimedia menjadi amat penting bagi guru agama.

3) Siswa semakin antusias dengan hadirnya pemanfaatan multimedia oleh guru agama terutama pada materi tatacara

4) penyembelihan hewan qurban.

5) Pengelompokkan siswa sudah merata, dengan jumlah siswa 30 orang bisa dibagi secara heterogen dan berdasar kemampuan.

Berdasarkan refleksi tersebut maka diputuskan untuk tidak mengadakan tahapan siklus berikutnya. Peningkatan hasil belajar siswa dari post test siklus I sampai post test siklus III seperti dinyatakan di atas juga dapat dilihat pada diagram peningkatan hasil belajar berikut.

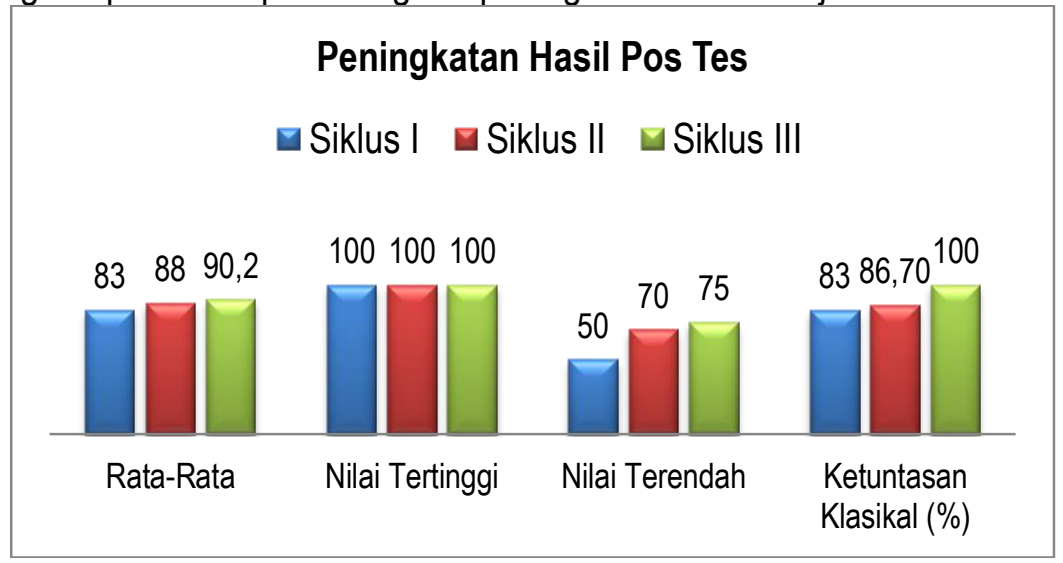

Gambar 1. Peningkatan Hasil Pos Tes

Gambar 1 menunjukkan secara nyata adanya peningkatan hasil belajar dari siklus I, II dan III. Nilai rata-rata siklus I mencapai 83 meningkat menjadi 88 pada siklus II dan meningkat lagi di siklus III dengan rata-rata 90,2, nilai tertinggi tetap 100 pada ketiga siklus, nilai terendah pada siklus I 
mencapai 50 naik menjadi 70 pada siklus II dan 75 pada siklus III. Sedangkan ketuntasan klasikal pada siklus I mencapai $83 \%$, meningkat pada siklus II menjadi $86,7 \%$ dan meningkat lagi menjadi $100 \%$ pada siklus III. Hal ini dapat diambil kesimpulan bahwa terjadi peningkatan hasil belajar yang signifikan dari siklus I hingga III.

\section{KESIMPULAN}

Berdasarkan hasil penelitian dan pembahasannya dapat disimpulkan bahwa :

1. Perencanaan penggunaan multimedia dalam pembelajaran PAI materi qurban dan aqiqah pada siklus I, II, dan III tergolong baik (70\% -100\%). Dengan demikian kemampuan Guru PAI dalam merencanaan penggunaan multimedia dalam pembelajaran PAI berkategori baik.

2. Penggunaan multimedia dalam pembelajaran PAI materi qurban dan aqiqah mengalami peningkatan ke arah baik. Siklus I, II, III memperoleh nilai baik (80\%, 97\% dan 100\%). Dengan demikian kemampuan Guru PAI menggunakan multimedia dalam pembelajaran berkategori baik.

3. Hasil belajar siswa mengalami peningkatan yang signifikan. Rata-rata siklus I sebesar 83 dengan ketuntasan klasikal 83\%, meningkat pada siklus II menjadi 88 dengan ketuntasan klasikal 86,7\% dan meningkat pada siklus III menjadi 90,2 dengan ketuntasan klasikal 100\%. Dengan demikian penggunaan multimedia dalam pembelajaran PAI dapat meningkatkan hasil belajar siswa pada materi qurban dan aqiqah.

Berdasarkan kesimpulan maka peneliti memberikan saran sebagai berikut:

1. Guru sebagai manager di kelas hendaknya mampu mendayagunakan berbagai media yang ada. Meskipun media-media itu bukan tujuan utama dalam pembelajaran, akan tetapi peran dan fungsinya sebagai alat bantu sangat penting dan menentukan terhadap pencapaian hasil belajar siswa;

2. Sekolah hendaknya menggunakan hasil penelitian tindakan kelas ini sebagai solusi untuk perbaikan proses pembelajaran dan mengusahakan secara maksimal ketersediaan media-media yang dianggap representatif dan efektif membantu para guru dalam mencapai tujuan pembelajaran;

3. Para peneliti khususnya peneliti di bidang pendidikan, hendaknya terus-menerus melaksanakan dan mengembangkan penelitian, sehingga hasilnya dapat dijadikan sumber rujukan bagi perbaikan pelaksanaan pendidikan sekarang dan di masa yang akan datang

\section{REKOMENDASI}

Desain penelitian ini terdiri dari dua siklus dan tiap siklus terdiri dari dua pertemuan. Sebaiknya jumlah pertemuan tiap siklus menyesuaikan dengan materi yang diteliti. Tidak selalu harus setiap siklus terdiri dari dua pertemuan.

\section{UCAPAN TERIMAKASIH}

Ucapan terima kasih ditujukan kepada kepala SMP Negeri 2 Ciamis dan kelas IX C tahun pelajaran 2017/2018 yang telah mendukung terhadap pelaksanaan penelitian ini.

\section{DAFTAR PUSTAKA}

Ahmad, T. (2004). Ilmu Pendidikan Dalam Perspektif Islam. Bandung: Remaja Rosda Karya

Buchori, M. (1994). Spektrum Problematika Pendidikan di Indonesia. Yogyakarta: Tiara Wacana.

Fathurrohman, P. (2001). Strategi Belajar Mengajar. Bandung: Tunas Nusantara.

Syah, M. (2006). Psikologi Belajar. Jakarta: PT. Raja Grapindo Persada. 